\title{
Polyols in confectionery: the route to sugar-free, reduced sugar and reduced calorie confectionery
}

\author{
Albert Zumbé, Adam Lee and David Storey* \\ Nutritional Biosciences Unit, Division of Biological Sciences, School of Environment and Life Sciences, The University of \\ Salford, Greater Manchester, M5 4WT, UK
}

\begin{abstract}
Polyol-containing confectionery offers considerable advantages over traditional sucrose-based confectionery in terms of reduced energy content and reduced cariogenicity. However, overconsumption of polyol confectionery may lead to gastrointestinal symptoms in some individuals. Rather than consider this as a distinct disadvantage to the consumer, this article discusses how careful consideration of the physico-chemical properties of polyols and advances in product development and formulation can provide suitable polyol-based products for the consumer. Furthermore, food legislation and ingredient pricing issues are just some of the factors that must be taken into account when designing new polyol-containing products if their functional benefits and good product quality are to be delivered to the consumer.
\end{abstract}

Polyols: Sucrose: Confectionery: Sugar free

Sugar confectionery has been developed over the centuries with increasing sophistication and it exists in countless formats with different degrees of sweetness, flavours and aromas, textures and mouthfeel. Confectionery serves a very simple purpose; the rush of sweetness coupled with pleasant flavours, aromas and mouthfeel provokes an almost instantaneous feeling of well-being and happiness (Lees \& Jackson, 1985; Jackson, 1990). Sugar confectionery by definition is meant to include products that contain predominantly one form or another of the following sugars: sucrose (usually cane or beet sugar); dextrose (otherwise known as glucose, usually corn sugar); fructose (often referred to a fruit sugar) or lactose (otherwise known as milk sugar). The different categories of sugar confectionery are shown in Table 1.

Because sucrose and glucose are relatively cheap and abundant, confectionery is readily available to the consumer. Thus, overconsumption of confectionery may lead to an excess intake of sugar, fat and energy which are implicated in the aetiology of dental caries, obesity and metabolic diseases associated with obesity (Department of Health, 1989, 1994). Health conscious individuals are aware of these factors and, given the pleasure that consumption of sugar confectionery can bring, may look for alternatives that are perceived to be 'better for you' yet taste just as good, and which they can continue to consume between meals. However, for many, reducing the amount and frequency of sugar confectionery consumption does not seem to be a desirable alternative.

Fortunately, a range of nutritive sweeteners called polyols (otherwise known as sugar alcohols) enable the confectioner to develop suitable sugar-reduced and nonsugar alternatives. These products are chemically defined as saccharide derivatives in which a ketone or aldehyde group is replaced by a hydroxyl group and include sorbitol, mannitol, maltitol, lactitol, isomalt, xylitol and erythritol (Fig. 1). Two non-polyol low-digestible carbohydrates (LDCs) that also have applications in sugar-free confectionery are D-tagatose and trehalose. These molecules provide bulk and texture, and have similar technological properties to sucrose and glucose (Sicard \& Leroy, 1983; Goosens \& Röper, 1994; Sicard \& Le Bot, 1994; Le Bot \& Gouy, 1995).

\section{Matching the properties of polyols with the consumer requirement}

Polyols have fewer calories per unit mass compared to sucrose (Ziesenitz \& Siebert, 1987) but actual permitted calorie claims differ according to local food legislation as outlined in Table 2. For food labelling purposes the European Union has agreed that in calculating the energy value of food, the calorific value of all polyols shall be $2.4 \mathrm{kcal} / \mathrm{g}$ compared to a value of $4 \mathrm{kcal} / \mathrm{g}$ for sugars and other carbohydrates (EC, 1990). In the USA, values have been allocated on a case-by-case basis (FASEB, 1994). For reduced-calorie confectionery containing polyols or reduced and non-calorie fats and/or added dietary fibre, product claims are regulated as outlined in Table 3. Clearly polyols can be used to replace some or all of the sugar which enables the development of non-sugar (sugar-free),

* Corresponding author: D. M. Storey, fax 0161295 5210, email d.m.storey@biosci.salford.ac.uk 

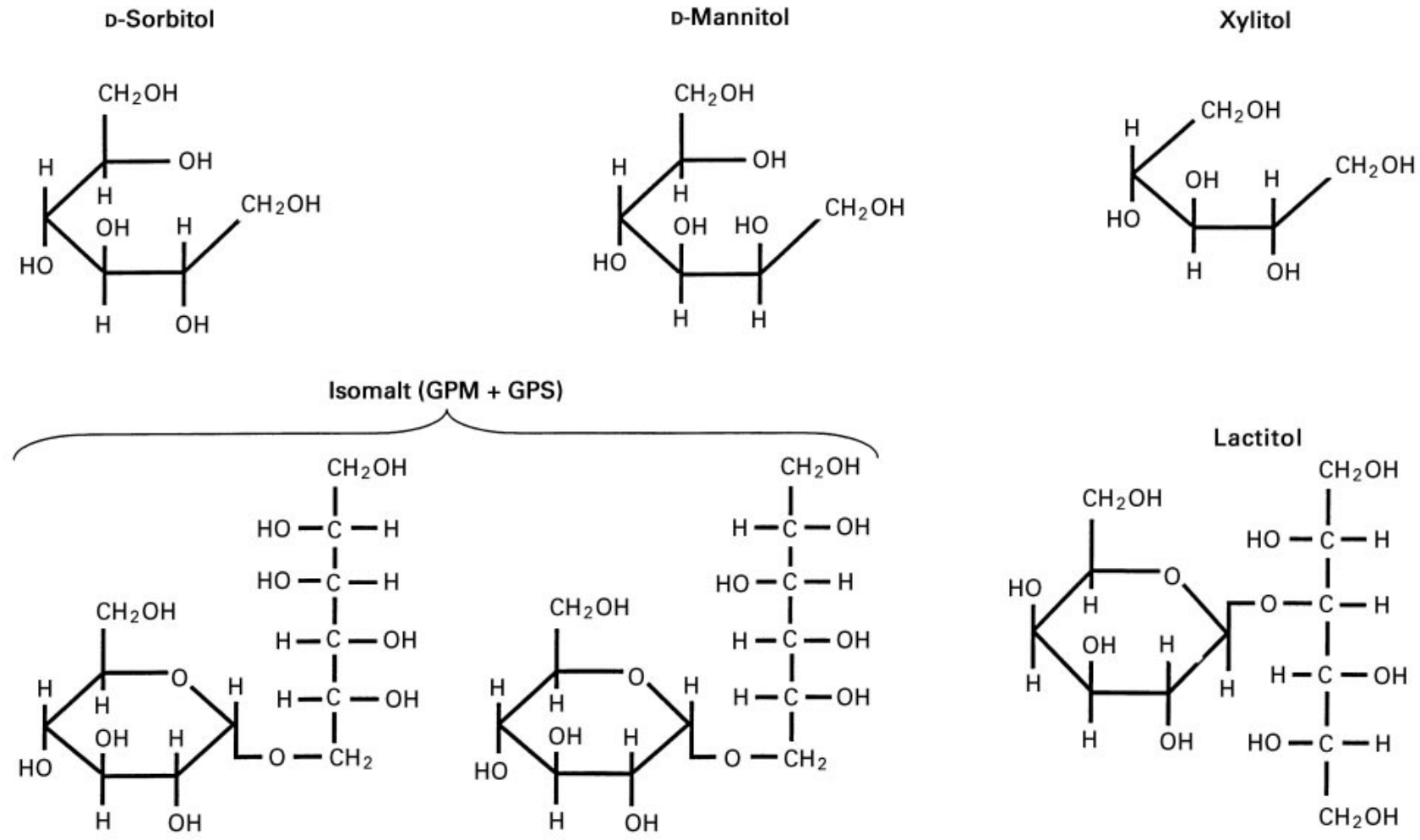

$\alpha$-D-glucopyranosyl-1,6-mannitol (GPM) $\quad \alpha$-D-glucopyranosyl-1,6-sorbitol (GPS)

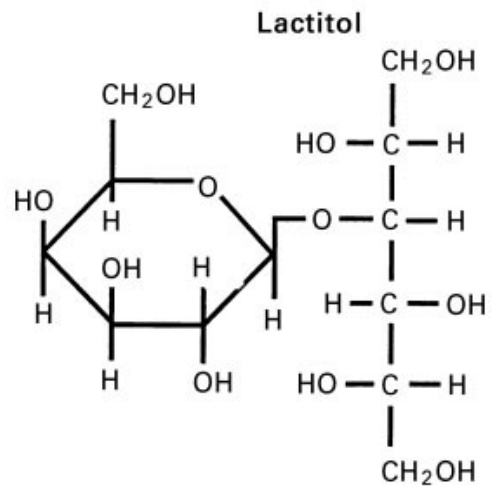

4-O- $\beta$-D-galactopyranosyl-D-sorbitol<smiles>OC[C@H](O)[C@H](O)[C@H](COC[C@H]1O[C@H](CO)[C@@H](O)[C@H](O)[C@H]1O)[C@H](O)CO</smiles>

Maltitol

4-O- $\alpha-D-g l u c o p y r a n o s y l-D-s o r b i t o l$

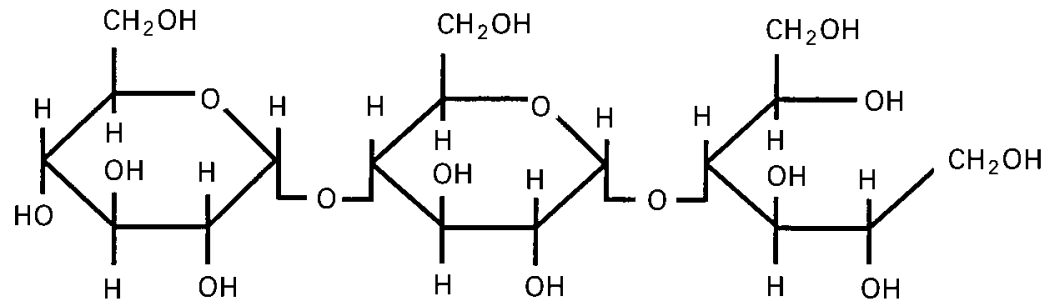

Maltotriitol

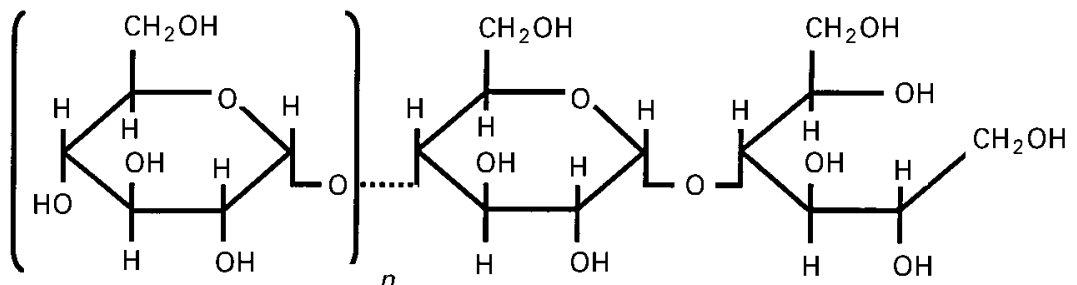

Hydrogenated gluco-oligosaccharides

Fig. 1. Chemical structure of some LDCs (Sicard \& Leroy, 1983; Sicard \& Le Bot, 1994; Goosens \& Röper, 1994; Le Bot \& Gouy, 1995). 
D-Tagatose<smiles>O=C(CO)C(O)C(O)C(O)CO</smiles>

Isomaltulose<smiles>O=C(CO)[C@H](O)[C@@H](O)[C@H](O)COC[C@H]1O[C@H](CO)[C@@H](O)[C@H](O)[C@H]1O</smiles>

Fig. 1. Continued.

reduced sugar, and no-added-sugar confectionery products. This is highlighted in Table 4.

\section{Sugar-related claims}

Streptococcus mutans is not the only oral bacterium capable of inducing dental caries, but is regarded as the most potent cariogenic organism and has been implicated in all types of dental caries (Loesche, 1986). However, polyol sugars are decidedly less cariogenic than sucrose, fructose, glucose and digestible carbohydrates that form part of our everyday diet (Grenby, 1982; Imfeld, 1983; Linke, 1987;

Table 1. Different categories of sugar confectionery (Lees \& Jackson, 1973; Jackson, 1990)

Boiled sweets (hard-boiled candy)

Toffee (caramel)

Fudge

Cremes

Gums and jellies

Liquorice

Marshmallow

Tablets

Lozenges

Chewing gum and bubble gum

Chocolate
Erythritol<smiles>OCC(O)C(O)CO</smiles>

Trehalose

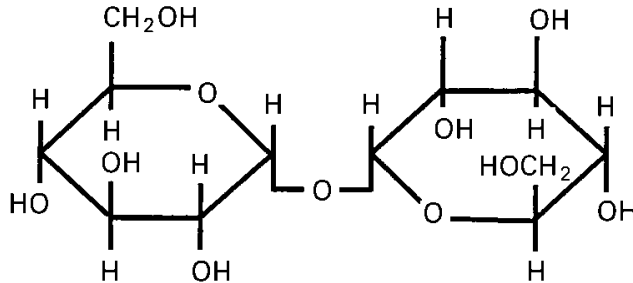

Ziesenitz \& Siebert, 1987). For example, $\mathrm{pH}$ telemetric curve data following oral rinsing with different polyol solutions demonstrates the lack of in vivo fermentation and acid production (Fig. 2). Furthermore, the inability of $S$. mutans Ingbritt to significantly ferment xylitol, erythritol, mannitol, sorbitol, lactitol, maltitol and isomalt in comparison to glucose over $48 \mathrm{~h}$ has been demonstrated (Fig. 3) (J Smullen, DM Storey and A Zumbé, unpublished results). Thus, confectionery products which contain polyols and which are sugar-free can be considered 'safe for teeth'.

\section{Cost of ingredient}

Polyols are much more expensive than standard sugar ingredients (Table 5) and as polyols vary in sweetness compared to sugar they often need to be supplemented with intense sweeteners slightly further increasing the total cost. So that polyol confectionery is favourably priced compared to sugar-containing confectionery, the portion size of many polyol products is often less than that of equivalent sugarcontaining products. Thus, the challenge for the marketing specialist assisted by the confectioner will be to design a product whereby the consumer does not focus on the net weight comparison with a sugar-based product. This is not an issue if the product under development is entirely new in conception and not a sugar-free version of an already 
Table 2. Calorific value of polyols (kcal/g) (EC, 1990; FASEB, 1994)

\begin{tabular}{|c|c|c|c|c|c|c|c|}
\hline & Sucrose & Sorbitol & Xylitol & Mannitol & Maltitol & Isomalt & Lactitol \\
\hline European Union & 4 & 2.4 & 2.4 & 2.4 & 2.4 & 2.4 & 2.4 \\
\hline USA & 4 & $2 \cdot 6$ & $2 \cdot 4$ & 1.6 & 3 & 2 & 2 \\
\hline Japan & 4 & 3 & 3 & 2 & 2 & 2 & 2 \\
\hline
\end{tabular}

Table 3. Reduced-calorie claims for food products

\begin{tabular}{|c|c|c|c|c|}
\hline Claim & EU & & USA & Japan \\
\hline \multirow[t]{4}{*}{ Energy reduced } & \multicolumn{2}{|c|}{ No provisions. Figures of individual member states apply. } & $\begin{array}{l}25 \% \text { reduction compared to } \\
\text { standard reference product }\end{array}$ & \\
\hline & $\left.\begin{array}{l}\text { Denmark } \\
\text { Finland } \\
\text { Germany } \\
\text { Greece } \\
\text { Spain }\end{array}\right\}$ & $\begin{array}{l}30 \% \text { reduction compared } \\
\text { to standard reference product }\end{array}$ & & \\
\hline & $\left.\begin{array}{l}\text { France } \\
\text { Netherlands }\end{array}\right\}$ & $\begin{array}{l}33 \% \text { reduction compared to } \\
\text { standard reference product }\end{array}$ & & \\
\hline & $\left.\begin{array}{l}\text { Sweden } \\
\text { UK }\end{array}\right\}$ & $\begin{array}{l}25 \% \text { reduction compared to } \\
\text { standard reference product }\end{array}$ & & \\
\hline Light & \multicolumn{2}{|r|}{ No food legislation definition } & $\begin{array}{l}\text { Product must have a reduction } \\
\text { of } 33 \% \text { calories and } 50 \% \text { fat. }\end{array}$ & \\
\hline Calorie free & \multicolumn{2}{|l|}{-} & - & $\begin{array}{l}<5 \mathrm{kcal} / 100 \mathrm{~g} \text { solid or } \\
100 \mathrm{ml} \text { liquid }\end{array}$ \\
\hline Non-calorie & \multirow{3}{*}{\multicolumn{2}{|c|}{-}} & & \\
\hline Reduced-carlorie & & & - & $\begin{array}{l}<40 \mathrm{kcal} / 100 \mathrm{~g} \text { solid or } \\
20 \mathrm{kcal} \text { liquid }\end{array}$ \\
\hline Low calorie & & & & \\
\hline
\end{tabular}

Table 4. Sugar related claims

\begin{tabular}{|c|c|c|c|}
\hline Claim & EU & USA & Japan \\
\hline $\begin{array}{l}\text { With no } \\
\text { added sugar }\end{array}$ & $\begin{array}{l}\text { Permitted in products whereby the } \\
\text { addition of extrinsic sugar is not an ingredient. } \\
\text { Addition of natural ingredients which contain intrinsic } \\
\text { sugars is permitted, e.g. milk which contains lactose. } \\
\text { There are no provisions, figures of individual member } \\
\text { states apply. } 0.5 \mathrm{~g} \text { residual sugar per } 10 \mathrm{~g} \text { product is } \\
\text { generally accepted. }\end{array}$ & & \\
\hline Sugar reduced & $\begin{array}{l}\text { France and the Netherlands require } 33 \% \text { and the UK } \\
\text { and Sweden } 25 \% \text {. }\end{array}$ & $\begin{array}{l}\text { The food must contain at least } \\
25 \% \text { less sugars than the reference } \\
\text { food and the label state the percentage } \\
\text { reduction and identity of the reference } \\
\text { food }\end{array}$ & $\begin{array}{l}<5 \mathrm{~g} / 100 \mathrm{~g} \text { solid or } \\
2.5 \mathrm{~g} / 100 \mathrm{ml} \text { liquid }\end{array}$ \\
\hline Sugar free & $\begin{array}{l}\text { There are no provisions, figures of individual member } \\
\text { states apply. } 0.5 \mathrm{~g} \text { residual sugar per } 10 \mathrm{~g} \text { product is } \\
\text { generally accepted. }\end{array}$ & $\begin{array}{l}\text { The food must contain less than } \\
0.5 \mathrm{~g} \text { sugars per serving and no } \\
\text { ingredient is sugar. It must be labelled } \\
\text { 'low calorie' or 'redued calorie' and meet } \\
\text { these requirements or it must have a label } \\
\text { statement 'not a reduced calorie food' } \\
\text { or 'not a low calorie food'. }\end{array}$ & $\begin{array}{l}<0.5 \mathrm{~g} / 100 \mathrm{~g} \text { solid } \\
\text { or } 100 \mathrm{ml} \text { liquid }\end{array}$ \\
\hline
\end{tabular}

existing product. Often this is not the case and the confectioner is faced with the challenge of creating a shape of similar size impression, but for which the unit weight is actually less. The actual size of each sweet may be reduced or the number of sweets in the pack may be reduced. Furthermore, for the more successful products the product pack will be designed in such a manner as to make it somewhat difficult to mentally compare the 'value for money' between the sugar-containing versus the polyolcontaining products. However, polyol products are weight for weight much more expensive ingredients than sugar and need to be marketed for the added benefits they inherently bring. Smaller portion sizes of polyol confectionery may also lessen the risk of gastrointestinal side-effects. 
$15 \mathrm{ml} 10 \%$ Xylitol $15 \mathrm{ml} 10 \%$ Sorbitol $15 \mathrm{ml} 10 \%$ Lycasin PC $\quad 15 \mathrm{ml} 10 \%$ Sucrose

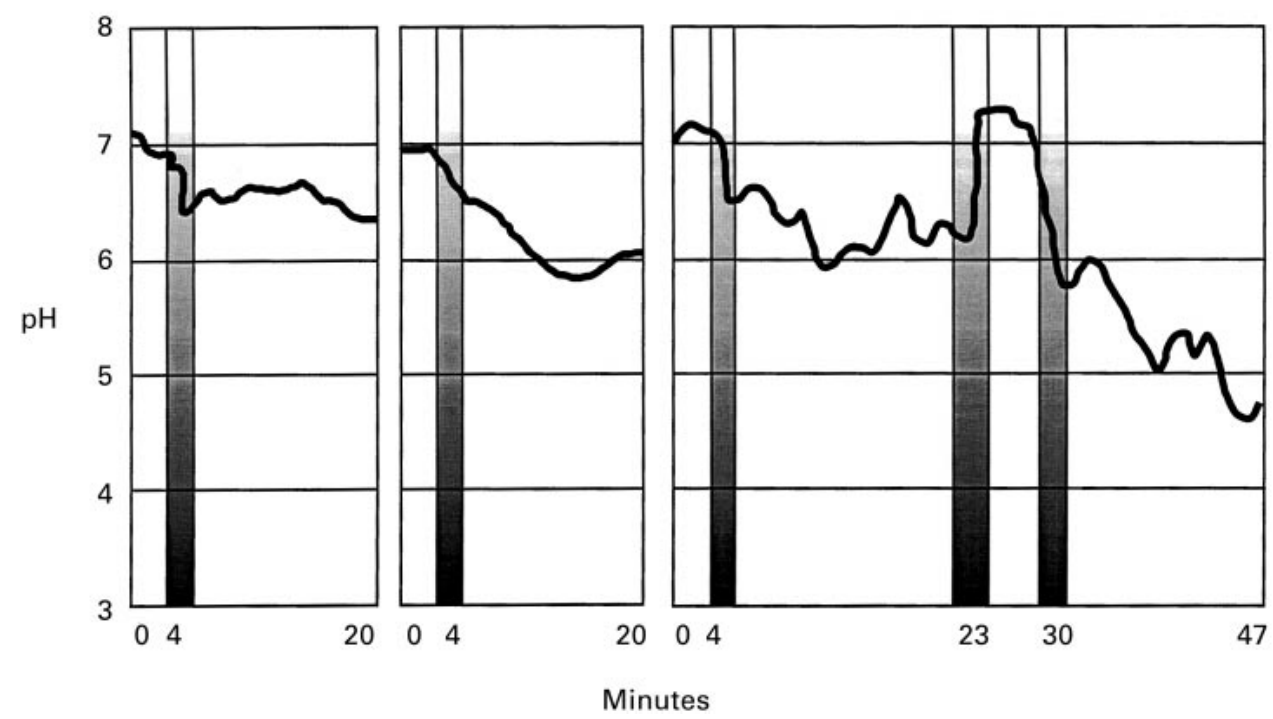

Fig. 2. Plaque $\mathrm{pH}$ response of some sugar substitutes (Adapted from Imfeld, 1983). PC, Paraffin chewing.

\section{Gastrointestinal tolerance of polyols}

Polyols are obviously completely safe for use in foodstuffs and are permitted food additives and ingredients (EC, 1994). However, it is accepted that they may induce perceivable transient gastrointestinal responses when consumed in excess (Zumbé et al. 1994; Storey \& Zumbé, 1995). Scientific data concerning the gastrointestinal tolerance of polyols reveals large inter- and intrasubject variations and the confectioner is well advised to read the scientific literature. However, there are few studies that actually compare the gastrointestinal tolerance of polyols in large study groups. Observed intolerance symptoms following polyol consumption and the dominant factors influencing tolerance are listed in Table 6 (Menzies, 1983). Thus, the challenge for the confectionery product formulator is to avoid certain polyols with low tolerance thresholds. For example, sorbitol has been largely abandoned as a bulk non-sugar ingredient by most manufacturers, in spite of the fact that it is relatively inexpensive and has excellent physical properties for the manufacture and stability of certain types of confectionery.

Some individuals can be very sensitive to even minimal ingested doses of polyols (Hyams, 1983) and although intolerant their reasons for being so may depend very much upon levels of ingestion of other LDCs in the diet. For the majority, consumption of the order of $20 \mathrm{~g}$ per person per day of polyols is unlikely to cause undesirable
Glucose

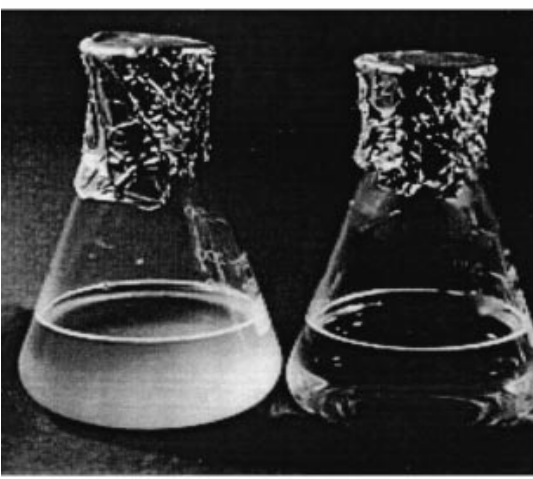

Turbid

Fermentation of carbohydrate $\mathrm{pH}$ drop Acid
Not turbid

No fermentation of carbohydrate No $\mathrm{pH}$ drop No acid
Glucose and polyol

Polyol

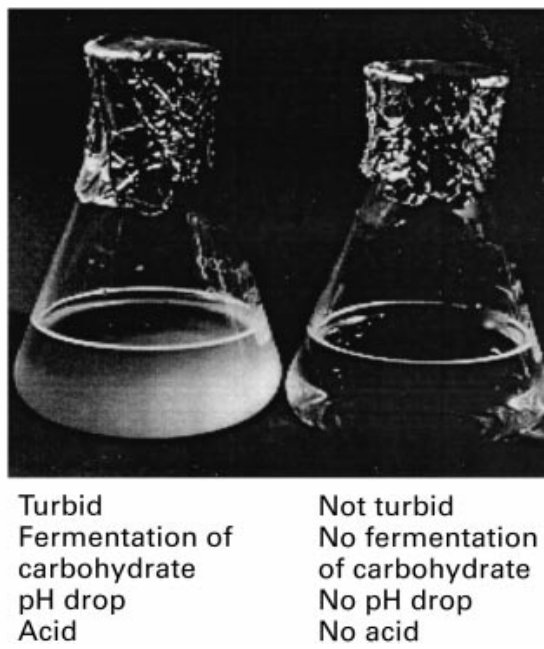

Fig. 3. Growth of Streptococcus mutans with or without different carbohydrate sources. Turbidity = increase in number of bacteria. (J Smullen, DM Storey and A Zumbé, unpublished results.) 
Table 5. Price indication of different sugars and polyols. Approximate price per $\mathrm{kg}$ on a dry weight basis ${ }^{\star \dagger}$

\begin{tabular}{lllr}
\hline Bulk sweeteners & \multicolumn{1}{c}{$£ / \mathrm{kg}$} & Intense sweeteners & $£ / \mathrm{kg}$ \\
\hline Sucrose & 0.44 & Saccharin & 1.72 \\
Glucose & 0.26 & Cyclamate & 1.42 \\
Fructose & 0.70 & Aspartame & 22.85 \\
Lactose & 0.35 & Acesulfame - k & 21.50 \\
Sorbitol & 0.96 & & \\
Mannitol & $1.40-1.57$ & & \\
Xylitol & $2.36-2.62$ & & \\
Maltitol & 1.40 & & \\
Isomalt & 1.40 & & \\
Lactitol & 1.31 & & \\
\hline
\end{tabular}

* The world price of crystalline sugar (sucrose) is about $£ 0 \cdot 14 / \mathrm{kg}$. In most countries including the EEC, USA and Japan there is an inflated intervention price of $£ 0.44 / \mathrm{kg}, £ 0.70 / \mathrm{kg}$ and $£ 0.74 / \mathrm{kg}$, respectively.

† Prices communicated by Roquette Freres, 62080 Lestrem, Cedex, France (1999). No price is available for erythritol because it has not been approved for use in the European Union.

gastrointestinal effects and laxation (Storey \& Zumbé, 1995). However, there are differences between the polyols in terms of tolerance. For example the disaccharide alcohol isomalt is tolerated better than the monosaccharide alcohol sorbitol, which exerts a greater osmotic load in the intestine (Zumbé \& Brinkworth, 1992; Lee et al. 1994).

Table 7 attempts to summarise the comparative tolerance for the different polyols, but needs to be interpreted with caution considering that strong mints are consumed much more slowly than gums and jellies and other factors affect tolerance (Table 6). These factors will need to be taken into account when the confectioner designs the recipe and portion size.

Within the European Union foodstuffs containing more than $10 \%$ of added polyols should bear the warning label 'excessive consumption may produce a laxative effect' (EC, 1996). In the USA, the label 'excess consumption may have a laxative effect' is mandatory on a case-by-case basis. For example, for sorbitol if the intake is 'more than
$>50$ g/day' (US Code of Federal Regulations (CFR) 184.1835) and for mannitol if the intake is 'more than $>20$ g/day' (CFR 180.25). For lactitol, maltitol and isomalt no statement is required. In Japan there are to date no regulations concerning mandatory laxative statements.

In this respect the hydrogenated higher oligosaccharides, e.g. the longer chain maltitol syrups are of particular interest since they potentially exert a far lower osmotic pressure in the gastrointestinal tract compared to other polyols. Thus, the tolerance thresholds that can be achieved with the hydrogenated higher oligosaccharides promise to be the best in the polyol category of ingredients. Products of this class, e.g. Lycasin are also non-cariogenic (Grenby \& Saldanha, 1988).

In order that manufacturers appreciate the potential risk of gastrointestinal discomfort following polyol consumption it is advisable for them to conduct scientifically designed and validated studies with products, with the participation of the target consumer group and accounting for the different patterns of expected consumption. This will enable marketing personnel to understand the potential risk of gastrointestinal discomfort, re-think whether the recipe mix and portion size are optimal in this respect, and finally evaluate this against the added perceived health benefits that particular products have to offer. There will always be a very low number of consumers that experience some discomfort and some of whom write to report their experience. The prudent manufacturer will have already generated their own tolerance data and will be in a much better position to respond constructively with relevant scientific data.

\section{The physico-chemical properties of polyols}

Polyols are available either in various crystalline forms or as liquid syrups and for some polyols both anhydrous and non-anhydrous crystalline forms exist. Table 8 shows some

Table 6. Intolerance symptoms following polyol consumption (Adapted from Menzies, 1983)

\begin{tabular}{|c|c|c|}
\hline Symptoms & Description & Main cause \\
\hline Laxation & $\begin{array}{l}\text { Increased bowel movement } \\
\text { frequency }\end{array}$ & $\begin{array}{l}\text { Osmotic effect of intact polyol and polyol } \\
\text { hydrolysates }\end{array}$ \\
\hline Diarrhoea & Watery or loose faeces & $\begin{array}{l}\text { Osmotic effect of intact polyol and polyol } \\
\text { hydrolysates }\end{array}$ \\
\hline Colic & Abdominal pain or discomfort & $\begin{array}{l}\text { Excess intestinal gas due to fermentation of } \\
\text { polyol and polyol hydrolysates }\end{array}$ \\
\hline Bloating & Abdominal distention & $\begin{array}{l}\text { Excess intestinal gas due to fermentation of } \\
\text { polyol and polyol hydrolysates }\end{array}$ \\
\hline Wind & Flatulence & $\begin{array}{l}\text { Excess intestinal gas due to fermentation of } \\
\text { polyol and polyol hydrolysates }\end{array}$ \\
\hline Borborygmi & Abdominal rumbling sounds & $\begin{array}{l}\text { Osmotic effect of intact polyal and polyol } \\
\text { hydrolysates }\end{array}$ \\
\hline \multicolumn{3}{|c|}{$\begin{array}{l}\text { Some factors that influence tolerance of polyols are: } \\
\text { 1. The type of polyol ingested be it a monosaccharide or disaccharide. } \\
\text { 2. The type of product ingested, i.e. hard-boiled sweets or chocolate which contains fat which may delay gastric emptying. } \\
\text { 3. The rate of consumption of product by an individual. } \\
\text { 4. The total quantity (dose of polyol) consumed by an individual. } \\
\text { 5. Consumption of product with or without meals or liquids. } \\
\text { 6. The level of other LDCs in the diet. } \\
\text { 7. Adaptation of the individual's colonic flora to polyols and other LDCs in the diet. } \\
\text { 8. The capacity of the individual to tolerate non-absorbable colonic fluid loads. } \\
\text { 9. The sensitivity of the individual to experience discomfort following colonic gas production. }\end{array}$} \\
\hline
\end{tabular}


Table 7. Comparative tolerance of polyols

\begin{tabular}{llll}
\hline Polyol & Description & Osmotic potential & Metabolism \\
\hline Sorbitol & Monosaccharide & Higher osmotic potential & Passively absorbed \\
Mannitol & Monosaccharide & & Passively absorbed \\
Lactitol & Disaccharide & & Minimally hydrolysed \\
Isomalt & Disaccharide & Partially hydrolysed \\
Maltitol & Disaccharide & Partially hydrolysed & Lower tolerance \\
Lycasin & Polysaccharide & Lower osmotic potential & Partially hydrolysed \\
\hline
\end{tabular}

of the physico-chemical properties that are considered by the manufacture when used in confectionery products (Sicard \& Leroy, 1983; Sicard \& Le Bot, 1994; Goosens \& Röper, 1994; Le Bot \& Gouy, 1995).

\section{Taste and sweetness}

All polyols have a pleasant, clean and neutral taste in solution. Their body, mouthfeel and taste profiles can be compared with those of sucrose. As the sweetness of most polyols is less than that of sucrose (Table 8) intense sweeteners are usually used to bring the overall sweetness up to the desired level (Sicard \& Le Bot, 1994; Zumbé et al. 1994). As some of the intense sweeteners are sensitive to heat, $\mathrm{pH}$ and/or humidity the confectioner will need to take the recipe and process into account when designing the sweetness levels of confectionery products.

\section{Solubility}

The solubility of different polyols varies with temperature (Fig. 4) and is an important factor in the manufacture of certain types of sugar confectionery whereby the use of a polyol syrup is necessary and the right choice of ingredient will minimise precipitation of crystal out of solution (Sicard \& Leroy, 1983; Sicard \& Le Bot, 1994; Goosens \& Röper, 1994; Le Bot \& Gouy, 1995). Equally, the time taken for the ingested sweet to dissolve into the saliva as it is sucked and/or broken up in the mouth will influence the rate and intensity at which the sweetness and added flavours act to create the required flavour boost and profile.

\section{Hygroscopicity}

The hygroscopicity of different polyols varies with relative humidity (Fig. 5 and Table 8). Moisture pick-up will limit the shelf life of a piece of candy as it will in time become sticky at the surface. Isomalt is an excellent ingredient as it does not pick up moisture easily, so individual hard-boiled sweets can be packed together in a box without the risk of product deterioration. In order to limit the moisture absorption of less stable formulations individual packaging for each piece of candy is necessary.

\section{Cooling effect}

A characteristic property of all polyols is their negative heat of solution (Table 8) which gives a cooling sensation in the mouth. The cooling sensation effect depends on: the heat of solution; the solubility of the polyol at mouth temperature $\left(36.4^{\circ} \mathrm{C}\right)$; the particle size (the finer the particles, the more quickly it dissolves thus contributing to the cooling sensation). For mints the cooling sensation is often a desired characteristic and for this reason xylitol is often used. In chocolate the cooling effect is minimised by the use of isomalt or maltitol.

\section{Diabetic confectionery}

The nutritional advice now given to diabetics is that they should eat normal foods, choose the right food and avoid products especially positioned for diabetics. Polyol-containing foods are potentially of interest to the diabetic because polyols have a low glycaemic index (Brunzell, 1978; Jenkins et al. 1981; Pelletier et al. 1994). For example, isomalt elicits a far lower postprandial plasma glucose response compared to sucrose (Fig. 6).

\section{Recipe and process}

The confectioner has a wide choice of polyols with different inherent physical and chemical properties to

Table 8. Physico-chemical properties of polyols (Adapted from Sicard \& Leroy, 1983; Sicard \& Le Bot, 1994; Goosens \& Röper, 1994; Le Bot \& Gouy, 1995)

\begin{tabular}{|c|c|c|c|c|c|c|c|c|c|}
\hline Powder form & Sucrose & Sorbitol & Xylitol & Mannitol & Maltitol & Isomalt & Lactitol & Lactitol & Erythritol \\
\hline Commercial form & \multicolumn{5}{|c|}{ Anhydrous } & 1/2 Anhydrous & Anhydrous & Monohydrate & Anhydrous \\
\hline Molecular weight & 342 & 182 & 152 & 182 & 344 & 355 & 344 & 362 & 122 \\
\hline Sweetness & $1 \cdot 0$ & 0.6 & 0.95 & 0.5 & 0.9 & 0.5 & 0.4 & 0.4 & 0.7 \\
\hline Heat of solution $\left(\mathrm{cal} / \mathrm{g}\right.$ at $25^{\circ} \mathrm{C}$ ) & $-4 \cdot 3$ & $-26 \cdot 5$ & $-36 \cdot 6$ & $-28 \cdot 9$ & $-16 \cdot 3$ & -9.4 & - & $-13 \cdot 9$ & $-23 \cdot 7$ \\
\hline Solubility at $20^{\circ} \mathrm{C}(\% \mathrm{DS})$ & 67 & 73 & 63 & 20 & 60 & 25 & - & 52 & 37 \\
\hline Solubility at $50^{\circ} \mathrm{C}(\% \mathrm{DS})$ & 72 & 83 & 80 & 31 & 70 & 45 & - & 74 & 55 \\
\hline Melting Point $\left({ }^{\circ} \mathrm{C}\right)$ & 184 & 99 & 94 & 165 & 147 & $145-150$ & 150 & 96 & 126 \\
\hline Hygroscopicity/ERH $-20^{\circ} \mathrm{C}$ in powder & 84 & 74 & 82 & 94 & 89 & 88 & $54-90$ & 90 & 91 \\
\hline
\end{tabular}

DS, Dissolved solids; ERH, equilibrium relative humidity. 


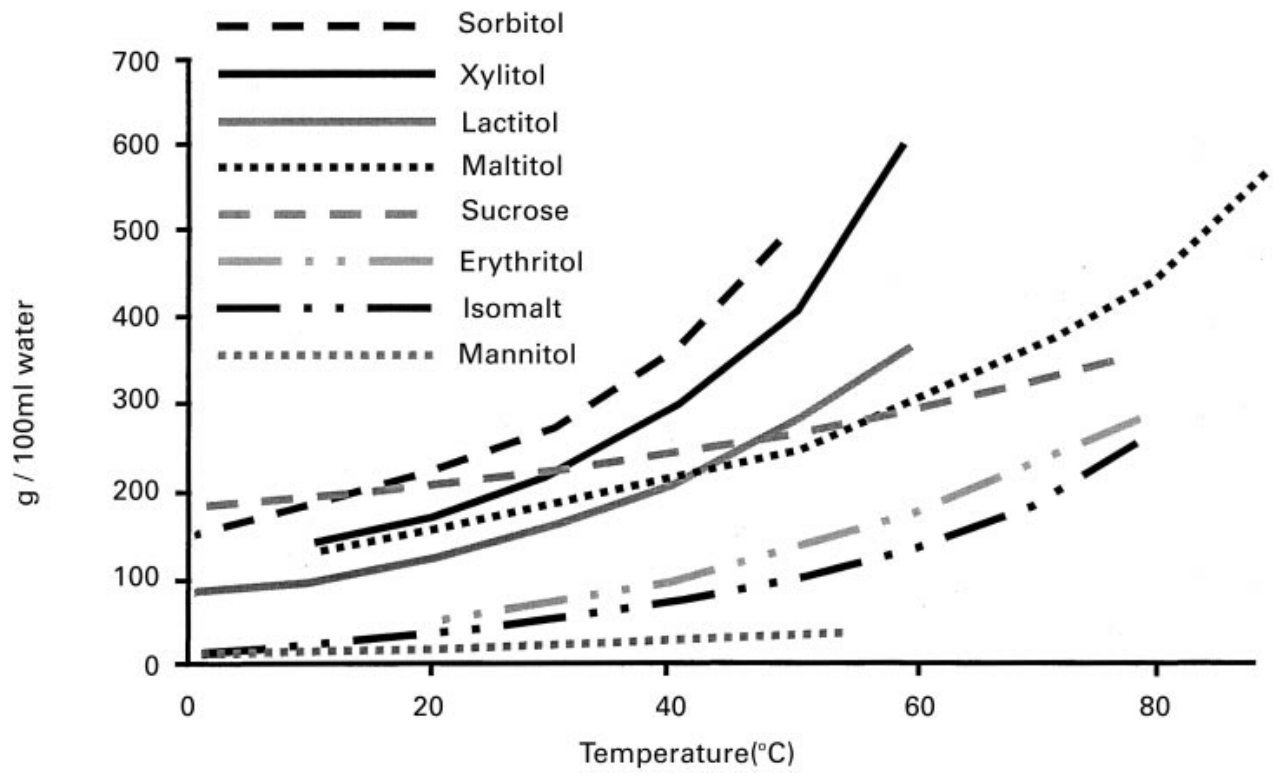

Fig. 4. Solubility of polyols (Roquette, 1998).

choose from enabling the manufacture of sugar alternatives of virtually every type. It is also advisable to give attention to the actual ingredient specification because for example the level of purity and/or particle size can be critical for the confectionery process for which it will be used. Some of the more common and successful applications are given in the following sections although the list is exhaustive and beyond the scope of this article. The following recipes, with the exception of some of the chocolate variations qualify for 'reduced sugar', 'reduced calorie' and 'tooth friendly' as defined by European Union food legislation. To qualify for the 'tooth friendly' claim the acid content of fruitflavoured sugar-free confectionery needs to be limited to pass in vivo $\mathrm{pH}$ telemetric tests.

\section{Chocolate}

Chocolate is defined as an almost anhydrous dispersion of fine, non-fat particles in a solid fat phase (Lees \& Jackson, 1985). Cocoa liquor, cocoa butter, sugar and milk are the four basic ingredients for making chocolate. By blending

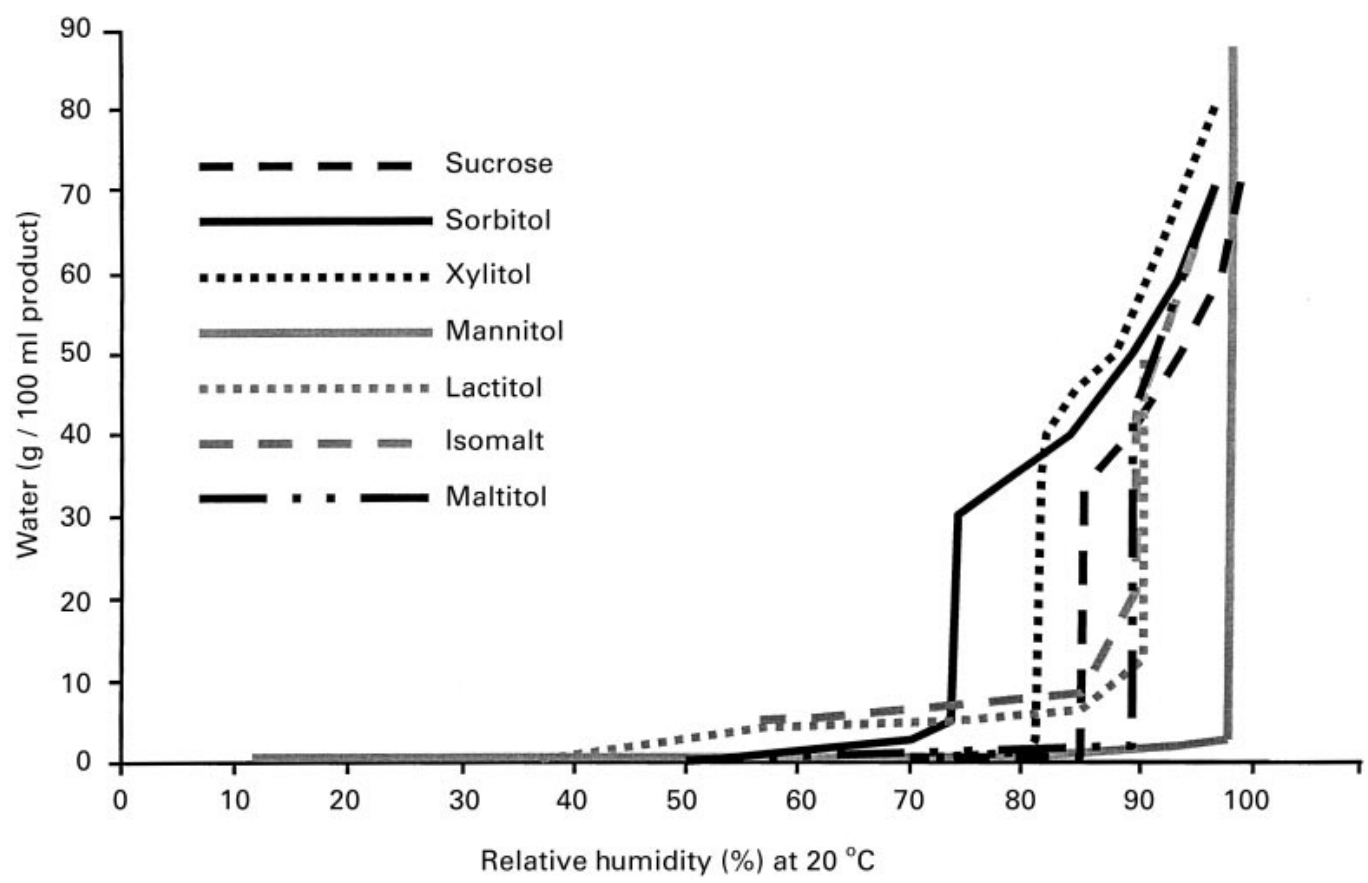

Fig. 5. Hygroscopicity of polyol crystalline powders (Roquette, 1998). 


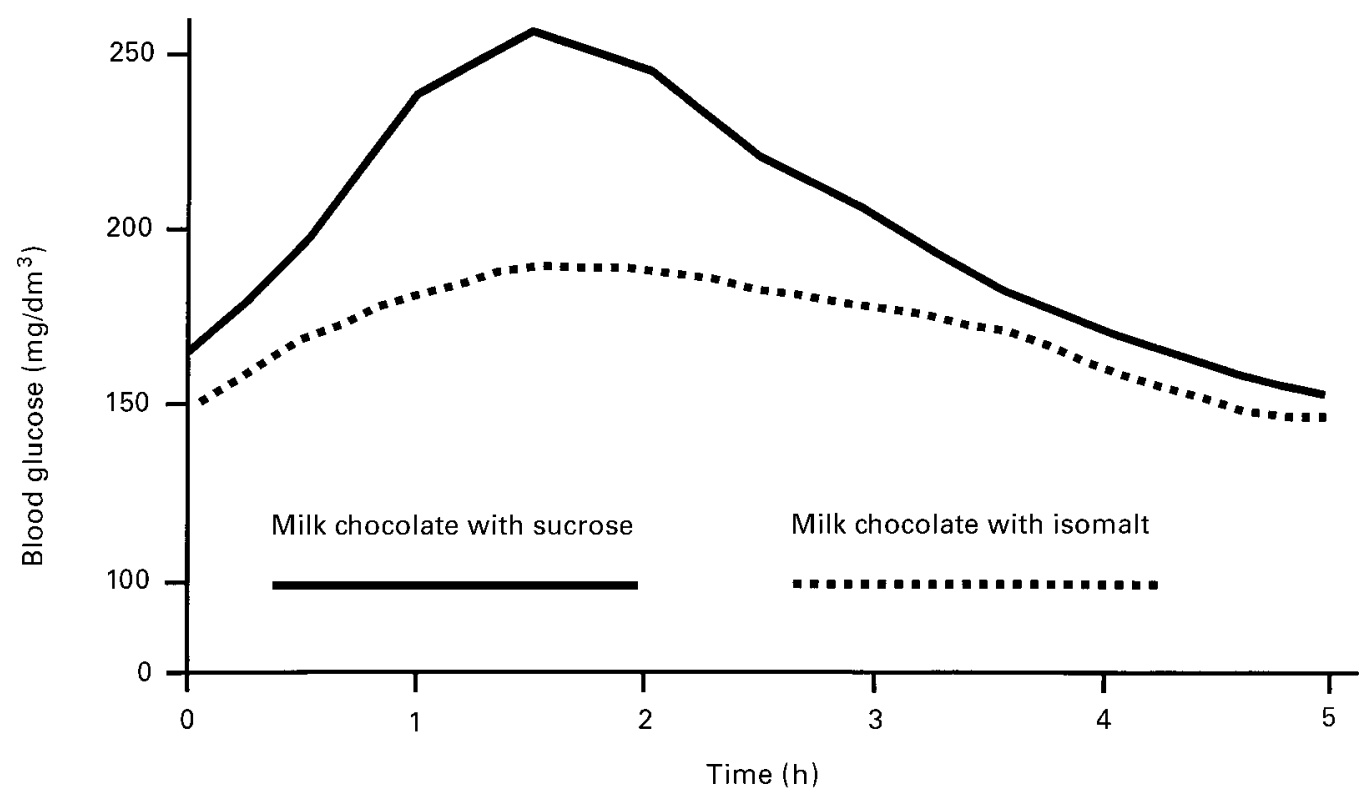

Fig. 6. Average blood glucose levels of type II diabetics following consumption of $70 \mathrm{~g}$ milk chocolate containing sucrose or isomalt (Adapted from Gee et al. 1991).

them in accordance with specific recipes the three basic types of chocolate are obtained.

Plain chocolate: cocoa liquor+cocoa butter+sugar Milk chocolate: cocoa liquor+cocoa butter+sugar+milk White chocolate: cocoa butter+sugar+milk

Polyols such as sorbitol, maltitol, isomalt and lactitol are all used to replace sucrose to manufacture sugar-reduced or sugar-free chocolate.

The use of anhydrous crystalline forms of polyols such as isomalt, maltitol and lactitol are much easier to work with from a process point of view. With non-anhydrous polyols the presence of a molecule of water of crystallisation during refining and conching can lead to recrystallisation and mass viscosity increase. Perfectly good chocolate can be made with the non-anhydrous polyols but great care must be taken to limit the temperature of the mix. For sorbitol, the limiting temperature in this respect is $42^{\circ} \mathrm{C}$ and for isomalt it is $45^{\circ} \mathrm{C}$. These polyols with the exception of isomalt are somewhat hygroscopic and care is needed during handling and processing to prevent moisture pickup. Excess moisture pick-up gives viscous chocolate which is difficult to mould and has an unpleasant sticky mouthfeel. Fig. 7 shows a simplified summary of chocolate processing.

Table 9 summarises the proposed standard of identity of European Union chocolate (EC, 1973). In standard chocolate, sucrose is a main recipe component. Lactose is found in milk powder (or more specifically $39.2 \%$ and $52.8 \%$ in whole and skimmed milk, respectively), and trace amounts of sugars are present in cocoa liquor. At present the maximum permitted added sugar content in chocolate is $55 \%$, although in the draft for harmonised European regulation this will no longer be regulated.

By manipulating the ingredient mix it is possible to design various recipes which would enable a particular product claim. These are listed as follows.

Reduced in sugar. To meet this requirement the total sugar component must not be more than three-quarters of that in a similar food for which the claim is made. In practice this means replacing the added sucrose with a

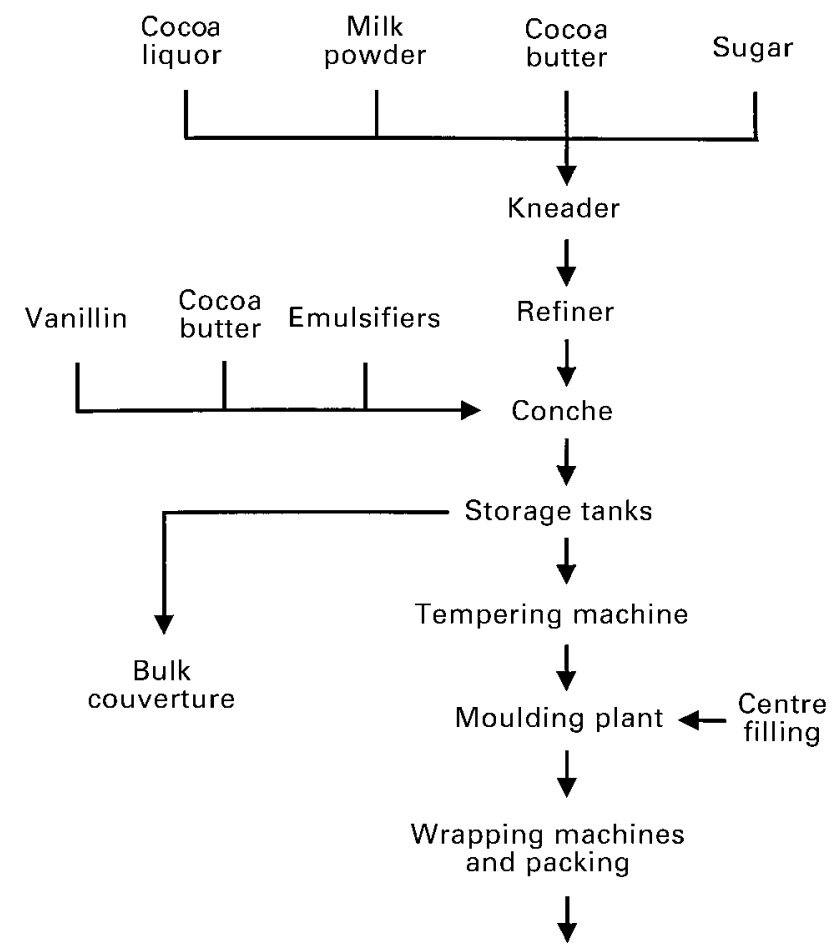

Storage and distribution

Fig. 7. Simplified summary of chocolate processing (Zumbe et al. 1994). 
Table 9. European Union standard of identity of milk chocolate (\% w/w) (EC, 1973). Aromas that have a chocolate or milk fat taste are not permitted. Non-cocoa vegetable fat is permitted in some products up to a level of $5 \%$

\begin{tabular}{|c|c|c|c|c|c|c|}
\hline & $\begin{array}{l}\text { Minimum dry } \\
\text { cocoa solids }\end{array}$ & $\begin{array}{l}\text { Minimum non-fat } \\
\text { cocoa solids }\end{array}$ & $\begin{array}{l}\text { Minimum dry } \\
\text { milk solids }\end{array}$ & $\begin{array}{l}\text { Minimum } \\
\text { milk fat }\end{array}$ & $\begin{array}{c}\text { Minimum } \\
\text { total fat }\end{array}$ & $\begin{array}{l}\text { Maximum } \\
\text { sugar }\end{array}$ \\
\hline Milk chocolate & 25 & 2.5 & 14 & 3.5 & 25 & 55 \\
\hline Quality milk chocolate & 30 & 2.5 & 18 & 4.5 & 25 & 50 \\
\hline Cooking milk chocolate & 20 & 2.5 & 20 & 5 & 25 & 55 \\
\hline Milk vermicelli/flake & 20 & 2.5 & 12 & 12 & 25 & 66 \\
\hline Gianduja nut milk chocolate* & 25 & 2.5 & 10 & $3 \cdot 5$ & 25 & 55 \\
\hline Couverture milk chocolate $†$ & 25 & 2.5 & 14 & 3.5 & 31 & 55 \\
\hline White chocolate $\neq$ & - & - & 14 & 3.5 & - & 55 \\
\hline
\end{tabular}

* Plus minimum $15 \%$ - maximum $40 \%$ hazlenut paste.

† Milk chocolate with high fat content typically $40 \% \mathrm{w} / \mathrm{w}$.

$\ddagger$ Plus minimum $20 \%$ cocoa butter.

polyol or a mixture of a polyol plus a low digestible carbohydrate (for example polydextrose or oligofructose). To meet the actual sugar claim it would not normally be necessary to replace all the added sugar, but the European sweeteners directive (EC, 1994) does not permit the use of sugar and polyols in the same recipe mix.

No added sugar. To meet this requirement the sugar (sucrose) ingredient is simply replaced as indicated above.

Sugar-free. These are truly non-cariogenic chocolate flavoured products which pass the in vivo telemetric test and are 'tooth-friendly'. With the exception of dark chocolate (which does not normally contain milk) they cannot be described as 'chocolate' because they do not conform with the standard of identity requirement. For milk and white chocolate in addition to the replacement of the added sugar, the milk powder is replaced by either:

- milk protein concentrate (lactose reduced)+milk fat (or typical example: $75 \%$ protein, $12 \%$ lactose and $1 \%$ fat)

- milk protein isolate e.g. sodium caseinate+milk fat

These recipes are by far the most difficult to develop because it is extremely difficult to create a good flavour. Not only is there a lack of sucrose necessary for caramelisation reactions but also a lack of reducing sugar i.e. lactose for maillard reactions which are normally created in the conching step of manufacture of standard chocolate. The confectioner usually compensates for this by the addition of reaction flavours. Caramelised milk powders are often used. The addition of flavours which have a milk or chocolate (cocoa) taste is strictly forbidden in the standard of identity of chocolate although for chocolate-like recipes such as 'sugar-free' this would not be a constraint.

Calorie-reduced chocolate. The substitution of sucrose by polyols will result in a calorie reduction. The calorie reduction attained by a total sucrose replacement is $12 \%$ (using the calorie value of $2.4 \mathrm{kcal} / \mathrm{g}$ for polyols under European legislation). This is somewhat short of the impending legislation of $30 \%$ calorie reduction for permitted product claims. Other LDCs for example inulin (oligofructose) and polydextrose with accepted calorie values of $1.0 \mathrm{kcal} / \mathrm{g}$ enable further calorie reduction. Quite acceptable oganoleptic properties can be achieved with a recipe mix of $50 \%$ polyol and $50 \%$ polydextrose.
However, calorie reductions of approaching $30 \%$ can be achieved; a typical example for dark chocolate is shown in Table 10. Such recipes tend to be rather viscous and have a 'dry' sticky mouthfeel. The mouthfeel can be somewhat masked by the use of specialised emulsifying agents and or breaking the chocolate up into smaller solid chunks as for example in aerated chocolate, flake chocolate or chocolate mass with inclusions. Further advances have been made by the use of novel process technology which is within the scope of the standard of identity of chocolate and by the use of fat replacers which would take the recipe outside the standard of identity of chocolate. It is recommended that portion sizes should not be excessive and limited to about $60 \mathrm{~g}$. The use of polydextrose or inulin (oligofructose) is also advisable in all non-sugar recipes as it will lower the required level of polyol and thus decrease even further the potential risk of gastrointestinal discomfort.

\section{Sugar-free chewing gum and bubble gum}

Sugar-free chewing gum has now managed to out-compete sugar-containing brands in most western countries. In sugar-free gum the sugar is replaced by a mixture of a bulk sweetener, e.g. a polyol, and an intense sweetener. The composition and manufacturing process of a typical sugarfree gum is shown in Fig. 8. In the early 1970s these chewing gums suffered from textural and short shelf-life problems, which meant that they very quickly became brittle, crumbly and stale. This has been overcome through

Table 10. Reduced calorie dark chocolate*

\begin{tabular}{lcc}
\hline Ingredient & Reduced calorie recipe & Standard recipe \\
\hline Cocoa liquor & 33.0 & 42.0 \\
Cocoa butter & 9.5 & 13.5 \\
Defatted cocoa powder & 10.5 & - \\
Sucrose & - & 44.0 \\
Polyol & 23.0 & - \\
Inulin & 23.0 & - \\
Lecithin & 0.48 & 0.48 \\
PGPR & 0.50 & - \\
Vanilla flavour & 0.02 & 0.02
\end{tabular}

PGPR, polyglyceryl polyricinoleate.

* Recipe and process communicated by Cerestar (UK) Ltd, Trafford Park, Manchester M17 IPA, UK (1999). 


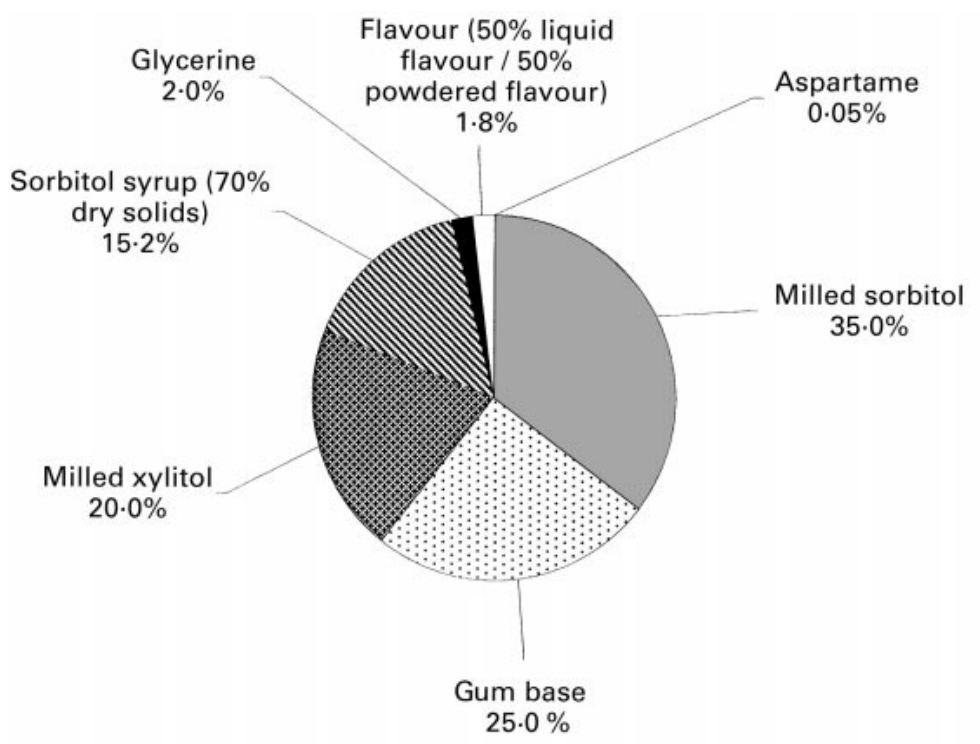

(1) The gum base is preheated to approximately $55^{\circ} \mathrm{C}$ prior to being transferred to a Z-blade kneader.

(2) Two-thirds of the sorbitol powder are added to the kneader and mixed with the softened gum base.

(3) The sorbitol liquid is added followed by the remaining sorbitol powder, xylitol and powdered flavours.

(4) The glycerine is combined with the liquid flavour and aspartame and added to the kneader.

(5) As soon as a homogenous paste is formed, the mixture is removed from the kneader and placed on a 'talc' dusted tray for $15-20 \mathrm{~min}$.

(6) The chewing gum portions are then extruded and processed as usual.

Fig. 8. Composition and manufacturing process of a typical sugar free chewing gum. Recipe and process communicated by Danisco Sweeteners, 41-51 Brighton Road, Redhill, Surrey RH1 6YS, UK (1999).

the use of specially adapted gum bases and polyol mixtures. Typically, sorbitol powder is used together with sorbitol or maltitol syrup, which provides the liquid phase, and aspartame or acesulfame $\mathrm{k}$ which is used to boost the sweetness. A proportion of mannitol may be used to inhibit the crystallisation. Sugar-free bubble gum recipes are essentially the same. Sugarless gum-based products, however, require much more careful handling, as the proportioning of crystallising and anti-crystallising phase ingredients is critical. As the portion size of these products is small there is no need to avoid the monosaccharide polyols, i.e. sorbitol or mannitol, because of the risk of gastrointestinal discomfort following consumption.

Xylitol is commonly used in chewing gum because it has the greatest cooling effect of all the available polyols and is also essential for mint-flavoured products (Pepper \& Olinger, 1988). Xylitol is not fermented by $S$. mutans (Hayes \& Roberts, 1978) but also, allegedly, inhibits the growth of $S$. mutans (Assev \& Rolla, 1984). Xylitol has been shown to decrease the amount of insoluble plaque polysaccharides, making the plaque less adhesive and easier to remove by brushing teeth. It also alters plaque composition which helps reduce plaque levels (Makinen \& Scheinin, 1982).

\section{Sugar-free hard panning}

Sugar and polyol panning is the process of building up a coating, layer by layer, on centres rotating in a pan. The coating may be hard or soft, depending on the thickness, composition and method of manufacture. Hard-panned confections have a hard crystalline coating and include products such as chocolate beans and chewing gum chiclets, whereas soft-panned products have a soft texture e.g. jelly beans. Sorbitol, xylitol, isomalt, maltitol and lactitol have all been successfully used for panning. Nonhygroscopic ingredients are best because there will be less moisture pick up and a prolonged shelf life. In this respect isomalt is an ideal ingredient for panning, and lactitol monohydrate is preferred over anhydrous lactitol. Nonhygroscopic panned coatings do not need to be individually packed to protect them against moisture pick up, and individual pieces of candy will not become sticky and clump together. The centres need to be sufficiently firm to 
Table 11. Composition and manufacture of isomalt hard boiled sugar-free confectionery*

\begin{tabular}{lc}
\hline Ingredient & $\%$ \\
\hline Isomalt & 75 \\
Water & 24 \\
Citric acid & 0.8 \\
Flavour & Add accordingly \\
Colour solution & Add accordingly \\
Intense sweetener (aspartame/acesulfame-k) & Depending on sweetening power \\
& \\
1. Cook Isomalt and water in a candy cooker up to 155-160 ${ }^{\circ} \mathrm{C}$ & \\
2. Apply a full vacuum for 5 min. & \\
3. Cool mass to $110-115^{\circ} \mathrm{C}$. & \\
4. Add acid, flavour, colour solution and intense sweetener. & \\
5. Process as usual. & \\
\hline * Recipe and process communicated by Palatinit Sussungsmittel GmbH Gottlieb-Damlier Strasse, 12a, Mannheim, \\
Germany, D-68165 (1999).
\end{tabular}

withstand their own weight when loaded into the pan and must not break up whilst tumbling. A sealing coat usually containing gum arabic is used to provide an even surface and to improve adhesion of the polyol coating.

\section{Sugar-free hard-boiled candy}

Boilings are high-cooked, coloured and flavoured sugar masses which are formed into sweets of desired shape and size by stamping or moulding. They are noncrystalline, clear and glossy in appearance. Whilst hard boilings can be manufactured with various polyols including sorbitol, maltitol and lactitol syrups and mixtures thereof, isomalt has proved to be particularly good for this application. Transparent sweets with a smooth glossy surface of comparable quality to the sugar standard can be relatively easily manufactured although the use of intense sweeteners is recommended. However, maltitol does not require sweetening because of its inherent sweetness. Isomalt hard boilings are extremely robust as they do not pick up moisture and can be packed without individual protection for prolonged periods. For hard boilings a vacuum cooker is required. A residual water content of below $1 \%$ is critical for hard-boiled candies in order to avoid a marked tendency to absorb moisture from the atmosphere although with isomalt this can be up to $2 \%$. Table 11 shows the composition and manufacture of isomalt hard boilings.

\section{Sugar-free toffee}

Toffee is an emulsion of fat in an aqueous system. It is a complex mixture of sugars, water and protein which is very resistant to crystallisation. The textural characteristics are very varied indeed. For example, hardness is a function of moisture content whereas chewiness and toughness will be influenced by the relative amounts of fat, protein and carbohydrate. It is beyond the scope of this article to describe the different types of manufacturing processes and the equipment used but a summary is given in Table 12. For sugar-containing and sugar-free toffee, the recipe and

Table 12. Formulation and processing of sugar-free toffee*

\begin{tabular}{lr}
\hline Ingredients & $\%$ \\
\hline Isomalt (type M) & $24 \cdot 20$ \\
Maltitol syrup ( $75 \%$ dry solids) & $5 \cdot 30$ \\
Water & $3 \cdot 55$ \\
Gelatine 120 bloom (40 \%) & $5 \cdot 80$ \\
Vegetable fat (34-36) & $0 \cdot 75$ \\
Emulsifier & $8 \cdot 70$ \\
Citric acid (monohydrate) & Add accordingly \\
Isomalt (extra fine type PF) & \\
Flavour & \\
1. Boil Isomalt, maltitol syrup and water at $132-136^{\circ} \mathrm{C}$, temperature depending on desired consistency of final product. \\
2. Add gelatine and stir until dissolved. \\
3. Add vegetable fat, emulsifier, citric acid, extra fine isomalt in the indicated order and stir at high speed for 2-3 min until homogenous. \\
4. Add flavour and mix, empty kettle. \\
5. Homogenise. \\
6. Cool the mass to $44-46^{\circ} \mathrm{C}$. \\
7. Pull the cooled mass for $5-10$ min at $47-49^{\circ} \mathrm{C}$. \\
8. Alternatively, homogenising and pulling can be replaced by using a pressure beating machine. \\
9. Cool the pulled mass until optimal consistency for processing has been reached. \\
10. Optimal water content is $6 \%$.
\end{tabular}

${ }^{*}$ Recipe and process communicated by Palatinit Sussungsmittel GmbH Gottlieb-Damlier Strasse 12a, Mannheim, Germany, D-68165 (1999). 
Table 13. Composition of gelatine gums $(\% \mathrm{w} / \mathrm{w})^{*}$

\begin{tabular}{lrccc}
\hline Gum texture & Soft & Medium & Hard & Pastilles \\
\hline Gelatine 220 bloom & \multicolumn{1}{c}{4.8} & 6.0 & - & - \\
Gelatine 260 bloom & \multicolumn{1}{c}{-} & - & 6.0 & - \\
Gelatine 270 bloom & \multicolumn{1}{c}{-} & - & - & 9.0 \\
Water & 9.6 & 12.0 & 12.0 & 13.0 \\
Maltitol syrup (75\% & 85.6 & 82.0 & 82.0 & 78.0 \\
maltitol dry weight) & & & & \\
Cooking temperature $\left({ }^{\circ} \mathrm{C}\right)$ & 112.0 & 112.0 & 114.0 & 125.0 \\
End moisture (\%) & 22.0 & 22.0 & 21.0 & 12.0 \\
\hline
\end{tabular}

* Recipe and process communicated by Cerestar (UK) Ltd, Trafford Park, Manchester M17 IPA, UK (1999).

process design needs to take into account the ratio of glucose syrup and sugar to obtain the required balance between the crystalline and amorphous phase to control the level of stickiness and short texture. Maltitol syrups correspond to glucose syrups whereas isomalt corresponds to sucrose, i.e. the crystallisation component of the formula. The sugar-free claims are achieved by addition of lactose free whey powder in recipes that would normally contain a milk ingredient. It is also necessary to add toffee and caramel colours to the cooled toffee mass because the polyol components do not react with proteins to give the characteristic taste and colours. In these ways it is possible to make excellent sugar-free toffees although the key is to achieve a controlled amount of crystallisation. It is recommended that an additional 7-9 \% of isomalt powder (extra fine grade) is added to the cooked mix and homogenised to accelerate graining (i.e. crystallisation) to the required level.

\section{Sugar-free gums and jellies}

This group of products ranging from hard gums to soft jellies is very large for which each product type is determined by the gelatinising agent and moisture content. For the purpose of this article two examples will be given, namely gelatine gums and pectin jellies.

Sugar-free gelatine gums. In these products formulation with maltitol syrup enables the gelatine to achieve its full gelling power. In sugar-free fruit-flavoured gums containing citric acid, it allows a reduction in gelatine level compared to standard gum whilst maintaining an identical profile. For non-acidified gums slightly more gelatine is required to achieve a similar texture to the standard. Maltitol syrups with more than $78 \%$ maltitol are not suitable because some of the maltitol crystallises on storage. Therefore, the manufacturing process is adapted slightly. Maltitol syrup ( $73 \%$ maltitol) is cooked to a dry substance of approximately $90 \%$ and before cooling to $90^{\circ} \mathrm{C}$, gelatine solution at $60^{\circ} \mathrm{C}$ is added. After cooling to $80^{\circ} \mathrm{C}$ citric acid flavour and colour are added. The mass is then deposited in dry moulded starch. A high dry syrup $(83 \%)$ is preferred as the syrup does not have an excessive viscosity and shortens the stoving period which can take a number of days to reach the correct dry solids content.

By modifying gelatine levels and type, maltitol syrup level, cooking temperature and stoving conditions any traditional texture profile from very soft to hard pastille types can be obtained (Table 13). However, in some instances a high solids syrup deposit can lead to the formation of small hard pieces due to non-homogenous gelling of the gelatin. Gelatine gums containing maltitol have additional advantages due to higher hygroscopicity and humectancy, which give better resistance to drying out than traditional gums, when stored at a low humidity. Thus, stickiness or deformation during storage are prevented.

Sugar-free pectin jellies. Maltitol syrup is an excellent polyol for pectin jellies. The final moisture content is increased slightly $(0.3-0.5 \%)$ to obtain an equivalent texture and shelf life to the traditional glucose-sucrose jellies, although a small amount of carragenan (0.4-0.5\%) is often added to increase the firmness for product stored at high temperature and humidity. A higher maltitol content of approximately $75 \%$ helps to prevent the pectin from setting too quickly, as does depositing at a temperature above $90^{\circ} \mathrm{C}$. The composition and manufacture of sugarfree pectin jellies is shown in Table 14 .

\section{Tabletting}

Confectionery tablets are made by compressing sugar powders in a die. The particles bond together under pressure and the compressed tablet is ejected from the die. For successful tabletting, the powder must be free flowing and able to bond together well under pressure. The particles must be sufficiently well bonded to withstand the force needed to eject the tablet from the die, and also be compact

Table 14. Composition and manufacture of pectin jellies*

\begin{tabular}{lr}
\hline Ingredient & $\%$ \\
\hline Maltitol syrup (75 \% maltitol dry weight) & $75 \cdot 8$ \\
Water & 22.4 \\
Pectin (high methoxy D100) & 1.8 \\
Citric acid 50 \% solution & 6.5 \\
Flavour and colour & Add accordingly
\end{tabular}

1. Mix $23 \%$ of the maltitol syrup with the water and heat to approximately $70^{\circ} \mathrm{C}$.

2. Add pectin to the syrup/water mix while stirring.

3. Heat slowly while stirring until the solution starts to boil. Boil for $2 \mathrm{~min}$.

4. Add the remaining maltitol syrup slowly (to avoid rapid cooling) and cook to $109^{\circ} \mathrm{C}$.

5. Add colour/flavour and citric acid solution and deposit immediately in starch (temperature of solution $90^{\circ} \mathrm{C}$ ).

6. After demoulding, the jellies are 'sanded' with crystalline maltitol powder.

* Recipe and process communicated by Cerestar (UK) Ltd, Trafford Park, Manchester M17 IPA, UK (1999). 
Table 15. Composition and formulation of sugar-free xylitol mint tablets*

\begin{tabular}{|c|c|c|}
\hline & Ingredients & $\%$ \\
\hline$A\{$ & $\begin{array}{l}\text { Xylitab } \\
\text { Flavour }\end{array}$ & $\begin{array}{r}98 \cdot 75 \\
0.25\end{array}$ \\
\hline$B\{$ & $\begin{array}{l}\text { Magnesium stearate } \\
\text { Stearic acid }\end{array}$ & $\begin{array}{l}0.50 \\
0.50\end{array}$ \\
\hline \multicolumn{3}{|c|}{$\begin{array}{l}\text { 1. Thoroughly blend the flavour into the xylitab. } \\
\text { 2. Mix the lubricant system B into mix A until } \\
\text { homogenous. Tablet specification: weight } 2 \mathrm{~g} \text {, hardness } 250 \mathrm{~N} \text {. }\end{array}$} \\
\hline
\end{tabular}

* Xyrofin (UK) Ltd (1996).

and hard enough to withstand subsequent handling. Powders that have these characteristics are called 'directly compressible' materials whereas other powders must go through an extra unit process called granulation. Sucrose typically requires granulating.

Sorbitol powder is an optimal polyol for sugar-free compressed tablets because it can be directly compressed to give hard, dense tablets which have a smooth texture and mouthfeel. However, sorbitol is hygroscopic and if not protected adequately will pick up moisture and the tablets will lose their consistency. Mannitol, xylitol and lactitol grades are also available for direct compressing and a special isomalt grade will shortly become available. Table 15 shows the composition and formulation of typical sugar-free xylitol mint tablets.

\section{Innovative developments}

Polyols have been successfully employed in virtually every type of confectionery, but considerable advances are being made to develop more sophisticated products with exacting claims and excellent gastrointestinal tolerance. Some of these innovative products are described as follows.

\section{Employment of higher levels of non-polyol LDCs}

A number of sugar-free and reduced calorie 'light' toffeelike products have recently appeared on the market. These products contain less than $10 \%$ polyol and about $90 \%$ polydextrose. Clearly, with such a low level of polyol the risk of gastrointestinal discomfort is reduced. Furthermore, within the European Union the regulations state that a product with less than $10 \%$ polyol does not require a laxative warning. Product formulators have, not surprisingly, gone to great lengths to develop suitable recipes.

Polydextrose usually contains a small amount of residual glucose which when tested alone or in a recipe with a large proportion of this ingredient would normally fail the in vivo telemetric 'toothfriendly' test. This has been overcome with a new hydrogenated polydextrose (Litesse 111) in which the residual glucose is converted into less cariogenic sorbitol. Commercially available oligofructoses also contain residual sugars and would fail in vivo telemetric tests. At present hydrogenated forms are unavailable.

\section{Erythritol}

Erythritol is a four-carbon polyol with an estimated low calorific value of below $0.5 \mathrm{kcal} / \mathrm{g}$ (Bornet et al. 1992). Erythritol is not fermented by S. mutans (Kawanabe et al. 1992) and the majority of an ingested dose is excreted in the urine (Bornet et al. 1996). Therefore, very little of the ingested dose remains in the upper intestine to cause osmotic effects or is available for colonic fermentation. It can be used for various applications including chewing gum and chocolate (Goosens \& Röper, 1994). It is also very useful for highly hygroscopic products, improving their conservation during storage. To date, erythritol has a selfasserted GRAS (generally regarded as safe) status in the USA but has not been approved within the European Union. As it is rather expensive, recipes will have to be developed in combination with other less-expensive polyols.

\section{New generation sugars}

These include sugars such as D-tagatose, trehalose and isomaltulose which are permitted food ingredients in Japan but not yet in the USA or the European Union. They are interesting ingredients for the development of 'toothfriendly' confectionery since isomaltulose and tagatose are hypoacidogenic in dental plaque (Imfeld, 1983; Maki et al. 1983). Furthermore, tagatose is hypocaloric compared to sucrose (Johansen \& Jensen, 1997) and is tolerated well in comparison to lactitol (Lee \& Storey, 1999). The gastrointestinal tolerance of isomaltulose remains to be investigated. Although there is a low level of fermentation of trehalose by S. mutans ingbritt, (J Smullen, DM Storey and A Zumbé, unpublished results) it may still be possible to design certain types of confectionery where trehalose is not a major ingredient and that pass the telemetric test for 'toothfriendly' confectionery.

\section{Conclusion}

Advances in product development and manufacturing techniques now enable utilisation of the full range of polyols and new generation sugars in confectionery products. These developments now offer the consumer the functional benefits of LDCs with regard to reduced energy products, reduced cariogenicity and other health benefits such as possible antineoplastic and prebiotic effects and reduced hyperlipidaemia (Scheppach et al. this issue). Many new products can now be developed with excellent taste and organoleptic properties, and avoid or at least reduce the risk of excessive gastrointestinal effects once associated with more traditional bulk sweeteners such as sorbitol and mannitol.

\section{References}

Assev S \& Rolla G (1984) Evidence for presence of xylitol phosphotransferase system in Streptococcus mutans OMZ 176. Acta Pathologica Microbiologica Immunologica Scandinavica (B Microbiol) 92, 89-92.

Bornet F, Blayo A, Dauchy F \& Slama G (1996) Gastrointestinal response and plasma and urine determinations in human 
subjects given erythritol. Regulatory Toxicology and Pharmacology 24, S296-S302.

Bornet F, Dauchy F, Chevalier A \& Slama G (1992) Étude du devenir métabolique aprés ingestion chez l'homme sain, d'un nouvel édulcorant de charge basses calorie: l'érythritol. Gastroenterologie Clinique et Biologique 16, A169.

Brunzell JD (1978) Use of fructose, sorbitol or xylitol as a sweetener in diabetes mellitus. Diabetes Care 1, 223-230.

Department of Health (1989) Dietary Sugars and Human Health, Reports on Health and Social Subjects, 37. London: HMSO.

Department of Health (1994) Nutritional Aspects of Cardiovascular Disease, Reports on Health and Social Subjects, 46. London: HMSO.

European Communities (1973) Council Directive 73/241/EEC on the approximation of the laws of the member states relating to cocoa and chocolate products intended for human consumption. Official Journal of the European Communities No. L228/23.

European Communities (1990) Council Directive 90/496/EEC of 24th of September 1990 on nutrition labelling for foodstuffs. Official Journal of the European Communities No. L 276, 6.10.90, pp. 40, Luxembourg.

European Communities (1994) European Parliament and Council Directive 94/35/EC of 30th June 1994 on sweeteners for use in foodstuffs. Official Journal of the European Communities No. L 237, 10.9.94 p3, as amended by Directive 96/83/EC of 19th December 1996, Official Journal of the European Communities No. L 48, 19.2.97 p16, Luxembourg.

FASEB (1994) The Evaluation of the Energy of Certain Sugar Alcohols Used as Food Ingredients. Bethesda, MD: Life Sciences Research Office, Federation of American Societies for Experimental Biology.

Gee JM, Cooke P, Gorick S, Wortley GM, Greenwood RH, Zumbé A \& Johnson IT (1991) Effects of conventional sucrose based, fructose based and isomalt based chocolates on postprandial metabolism in non insulin dependant diabetics. European Journal of Clinical Nutrition 45, 561-566.

Goosens J \& Röper H (1994) Erythritol: a new sweetener. Food Science and Technology Today 38, 144-149.

Grenby TH (1982) Nutritive sucrose substitutes and dental health. In Developments in Sweeteners - 2, pp. 51-88 [TH Grenby, KJ Parker and MG Lindley, editors]. London: Applied Science Publishers.

Grenby TH \& Saldanha MG (1988) Comparison of lycasin versus sucrose sweets in demineralisation studies of human enamel and hydroxylapatite. Caries Research 22, 269-275.

Hayes M \& Roberts K (1978) The breakdown of glucose, xylitol and other sugar alcohols by human dental plaque bacteria. Archives of Oral Biology 23, 445-451.

Hyams JS (1983) Sorbitol intolerance: an unappreciated cause of functional gastrointestinal complaints. Gastroenterology 84, 3033.

Imfeld TN (1983) Non-nutritive sweeteners, sugar substitutes and confectionery products. In Identification of Low Caries Risk Dietary Components, pp. 117-141 [HM Myers, editor]. Monographs in Oral Science. London: Karger.

Jackson BB (editor). (1990) Sugar confectionery manufacture. Glasgow: Blackie.

Jenkins JDA, Wolever THS \& Taylor RH (1981) Glycaemic index of foods: a physiological basis for carbohydrates exchange. American Journal of Clinical Nutrition 34, 362-366.

Johansen HN \& Jensen BB (1997) Recovery of energy as SCFA after microbial fermentation of D-tagatose. International Journal of Obesity Suppl 221, S50.

Kawanabe J, Hirasawa M, Takeuchi T, Oda T \& Ikeda T (1992) Noncariogenicity of erythritol as a substrate. Caries Research 26, 358-362.

Le Bot Y \& Gouy PA (1995) Polyols from starch. In Handbook of Starch Hydrolysis Products and Their Derivatives, pp. 155-176
[MW Kearsley and SC Dziedzic, editors]. London: Blackie Academic \& Professional.

Lee A, Storey DM \& Zumbé A (1994) Breath hydrogen after ingestion of the bulk sweeteners sorbitol, isomalt and sucrose in chocolate. British Journal of Nutrition 71, 731-737.

Lee A \& Storey DM (1999) Comparative gastrointestinal tolerance of sucrose lactitol, or D-tagatose in chocolate. Regulatory Toxicology and Pharmacology 29, S78-S82.

Lees R \& Jackson BB (editors). (1985) Sugar Confection and Chocolate Manufacture. Glasgow: Leonard Hill (Blackie Publishing Group).

Linke HAB (1987) Sweeteners and dental health: the influence of sugar substitutes on oral microorganisms. In Developments in Sweeteners - 3, pp. 151-188 [TH Grenby, editor]. London: Elsevier Applied Science.

Loesche WJ (1986) The effect of sugar alcohols on plaque saliva level of Streptococcus mutans. Swedish Dental Journal 8, 125135.

Maki Y, Ohta K, Takazoe I, Matsukubo Y, Takaesu Y, Topitsoglou V \& Frostell G (1983) Acid production from isomaltulose, sucrose, sorbitol and xylitol in suspensions of human dental plaque. Caries Research 17, 335-339.

Makinen KK \& Scheinin A (1982) Xylitol and dental caries. Annual Review of Nutrition 2, 133-155.

Menzies IS (1983) Medical importance of sugars in the alimentary tract. In Developments in Sweeteners - 2, pp. 89-118 [TH Grenby, KJ Parker and MG Lindley, editors]. London: Applied Science Publishers.

Pelletier X, Hannesse B, Bornet F \& Derby G (1994) Glycaemic and insulinaemic responses in healthy volunteers upon ingestion of maltitol and hydrogenated glucose syrups. Diabete and Metabolism 20, 291-296.

Pepper T \& Olinger M (1988) Xylitol in sugar-free confections. Food Technology 1042, 98-105.

Roquette (1998) Polyols. Roquette Freres, 62080 Lestrem, Cedex, France.

Sicard PJ \& Le Bot Y (1994) Manufacturing opportunities with non-sugar sweeteners. In Sugarless - Towards the Year 2000, pp. 112-135 [AJ Rugg-Gunn, editor]. Cambridge: Royal Society of Chemistry.

Sicard PJ \& Leroy P (1983) Mannitol, sorbitol and lycasin: properties and food applications. In Developments in Sweeteners - 2, pp. 1-25 [TH Grenby, KJ Parker and MG Lindley, editors]. London: Applied Science Publishers.

Storey DM \& Zumbé A (1995) Physiology, metabolism and tolerance of digestible and low digestible carbohydrates. In Handbook of Starch Hydrolysis Products and Their Derivatives, pp. 178-229 [MW Kearsley and SC Dziedzic, editors]. London: Blackie Academic \& Professional.

US Code of Federal Regulations, Washington DC: 21 CFR 180.25.

US Code of Federal Regulations, Washington DC: 21 CFR 184.1835.

Xyrofin (UK) Ltd (1996) Xylitab: Directly compressible xylitol. Danisco Sweeteners Brochure, Danisco Sweeteners, 41-51 Brighton Rd, Redhill, Surrey RH1 6YS, UK.

Ziesenitz SC \& Siebert G (1987) The metabolism and utilisation of polyols and other bulk sweetners compared with sugar. In Developments in Sweeteners - 3, pp. 109-149 [TH Grenby, editor]. London: Elsevier Applied Science.

Zumbé A \& Brinkworth R (1992) Comparative studies of gastrointestinal tolerance and acceptability of milk chocolate containing either sucrose, isomalt or sorbitol in healthy consumers and type II diabetics. Zeitschrift für Ernährungswissenschaft 31, 40-48.

Zumbé A, Lee A \& Storey DM (1994) Manufacture and marketing of non-sugar chocolate. In Sugarless - Towards the Year 2000, pp. 47-71 [AJ Rugg-Gunn, editor]. Cambridge: Royal Society of Chemistry. 